\title{
Anti-Hu limbic encephalitis preceding the appearance of mediastinal germinoma by 9 years
}

\author{
Matthew Silsby, MBBS (Hons), FRACP, Candice J. Clarke, BSc (Hons), MSc (MBT), MBA, \\ Kenneth Lee, MBChB, FRCPA, and David Sharpe, MRCP(UK), FRACP
}

Neurol Neuroimmunol Neuroinflamm 2020;7:e685. doi:10.1212/NXI.0000000000000685

\author{
Correspondence \\ Dr. Silsby \\ matthew.silsby@sydney.edu.au.
}

Autoimmune limbic encephalitis is characterized by the subacute onset of seizures, short-term memory loss, and confusion and can have a paraneoplastic or nonparaneoplastic etiology. ${ }^{1}$ Anti-Hu limbic encephalitis is typically paraneoplastic, most frequently associated with smallcell lung cancer. ${ }^{2}$ We report the case of a 28 -year-old man diagnosed with a mediastinal germ cell tumor 9 years after presenting with anti-Hu-positive limbic encephalitis.

\section{Case report}

A 19-year-old man presented after a generalized tonic-clonic seizure after several days of headaches and confusion. He had no medical history and did not take regular medications. There was no history of drug use, and he was a nonsmoker. There was no focal neurologic deficit on examination.

Electroencephalography demonstrated right temporal spike and slow wave activity. Brain MRI showed hyperintensity in the right medial temporal lobe on T2 FLAIR sequence, without gadolinium enhancement (figure, A). CSF showed 3 monocytes, and the protein level was slightly elevated $(0.48 \mathrm{~g} / \mathrm{L}, \mathrm{NR} 0.15-0.45 \mathrm{~g} / \mathrm{L})$. He was diagnosed with viral encephalitis.

At the age of 21 years, he re-presented with seizures, confusion, emotional lability, night sweats, and short-term memory loss. MRI demonstrated ongoing T2 FLAIR hyperintensity in the right medial temporal lobe. Further workup revealed serum anti-Hu antibodies by immunofluorescence (Inova Diagnostics, CA), confirmed by line immunoblot (Euroimmun Lubeck, Germany). Other antibodies, including amphiphysin, CRMP5, Ma2, Yo, Ri, titin, recoverin, SOX-1, and VGKC, were negative. He was diagnosed with paraneoplastic limbic encephalitis as per the guidelines by Graus. ${ }^{1}$

The CT scan of chest, abdomen, and pelvis was negative for malignancy, and whole-body PET was normal. Ultrasound revealed microcalcifications in the right testis. Alfa-fetoprotein and $\beta$-human chorionic gonadotropin ( $\beta$-hCG) were negative.

He was managed with IV cyclophosphamide $0.75 \mathrm{~g} / \mathrm{m}^{2}$ monthly for 6 months as per the National Institute of Health (NIH) protocol, IV methylprednisolone $1000 \mathrm{mg}$ daily for 5 days, and IV immunoglobulin (IVIG) $0.4 \mathrm{~g} / \mathrm{kg} / \mathrm{d}$ for 5 days. This was followed by oral prednisone $50 \mathrm{mg}$ daily, weaned to $10 \mathrm{mg}$ daily after several weeks, azathioprine $50 \mathrm{mg}$ twice daily (1.33 $\mathrm{mg} / \mathrm{kg} / \mathrm{d}$ ), IVIG $0.4 \mathrm{~g} / \mathrm{kg} 1$ day per month, and antiepileptic therapy.

His condition followed a fluctuating course, and repeated malignancy screening remained negative. Right orchiectomy was performed at the age of 24 years; however, findings were nonspecific and his condition remained unchanged. At the age of 26 years, a single course of rituximab $1000 \mathrm{mg}$ was given in response to radiologic relapse, after which neuropsychometric parameters and MRI mildly improved. Azathioprine and IVIG continued throughout; prednisone was ceased after a slow wean over 3 years. 


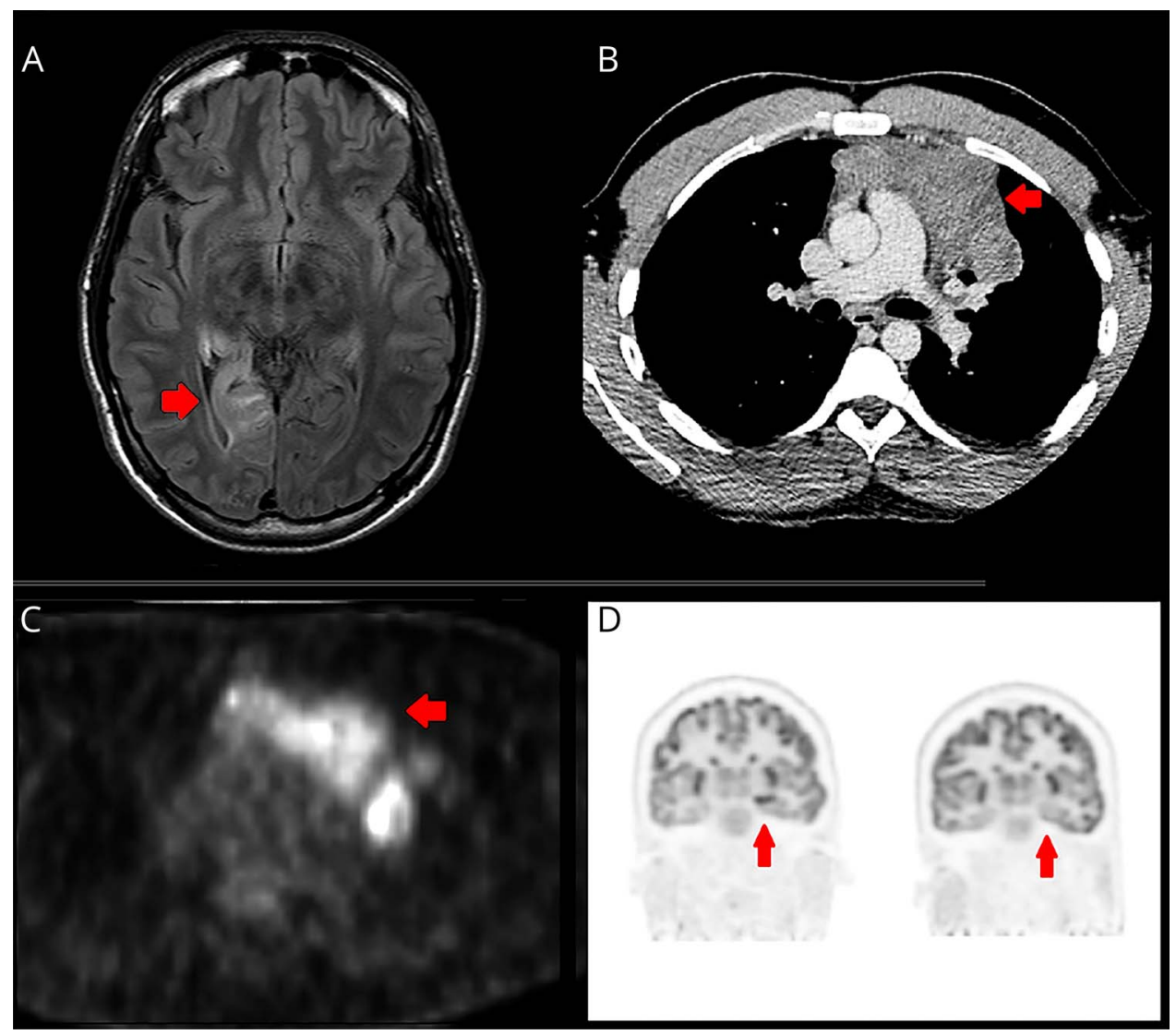

(A) Axial T2 fluid attenuated inversion recovery (FLAIR) MRI of the brain showing hyperintensity in the right medial temporal lobe at the age of 22 years. (B) Large anterior mediastinal mass diagnosed at the age of 28 years as demonstrated on CT chest. (C) Large anterior mediastinal mass (age 28) demonstrating high glucose avidity on PET-CT. (D) Left: Markedly increased metabolism in the left anteromesial temporal lobe and hippocampus. Right: Resolution of those changes 11 months after resection of the mediastinal tumor.

At the age of 28 years, he re-presented with pleuritic chest pain. CT scan demonstrated a large anterior mediastinal soft-tissue lesion measuring $107 \mathrm{~mm}$, which was highly glucose avid on PET (figure, B and C). Biopsy revealed a nonseminomatous germ cell tumor. Serum alfa-fetoprotein was $954 \mathrm{kIU} / \mathrm{L}$ (NR $0-6$ ), and serum $\beta$-hCG 19 IU/L (NR 0-5). Serum anti-Hu remained positive, and all other antibodies remained negative.

Immunotherapy was ceased, and he received bleomycin, etoposide, and cisplatin (BEP) 2 months before surgical resection. Pathologic assessment showed a mixed germ cell tumor with low grade sarcomatous components. Immunohistochemistry was performed on permeabilized formalin-fixed paraffinembedded tissue with $\mathrm{HuD}$ antibody at a dilution of 1:100 on an automated Leica Bond III. Tumor tissue was compared with normal brain as a positive control; however, it did not stain positive.

He has been neurologically stable for 3 years postoperatively and has now been able to undertake a vocational training course. He is no longer receiving immunotherapy. Lung recurrences 6 months and 2 years postoperatively required repeat resection and chemoradiotherapy. Neurologic PET, 11 months postoperatively, demonstrated resolution of previously persistent temporal lobe changes (figure, D).

\section{Discussion}

Our patient presented with paraneoplastic limbic encephalitis, presumably since the age of 19 years. However, it was not until 9 years later that malignancy was detected. Paraneoplastic limbic encephalitis frequently precedes the diagnosis of an underlying malignancy; ${ }^{2}$ however, the current criteria for diagnosis include demonstration of malignancy within $4^{2}$ or $5^{1}$ years.

Anti-Hu antibodies are associated with malignancy in more than $95 \%$ of cases, so the eventual detection of malignancy as in our case should not be surprising. It is more typical that $\mathrm{Hu}$ antibodies are associated with small-cell lung cancer, ${ }^{3}$ although a mediastinal germinoma has been reported. ${ }^{4}$ It is possible that testicular microcalcifications were evidence of earlier immunologic activity, especially given the development of a germ cell tumor.

This very long delay between $\mathrm{Hu}$ antibody positivity and the diagnosis of malignancy is atypical. Similar cases include detection of small-cell lung cancer 5.5 years after anti-Huassociated subacute sensory neuronopathy, ${ }^{5}$ lung carcinoid detected 8 years after initial diagnosis of anti-Ri antibodies, ${ }^{6}$ and 2 patients in whom malignancy developed 4.5 and 10 years, respectively, after detection of anti-Yo antibodyassociated cerebellar degeneration. ${ }^{7}$ 
Although our patient's tumor did not stain positive for anti$\mathrm{Hu}$, it was likely responsible for his syndrome, as evidenced by his improvement after resection. Negative staining might be explained by preanalytical fixation of the tissue influencing the binding capacity of the antibody or a lack of specificity to particular epitopes on the tumor itself.

The long delay between the detection of anti-Hu antibodies and the diagnosis of malignancy in this case highlights the importance of ongoing surveillance for malignancy in the presence of onconeuronal antibodies.

\section{Study Funding}

No targeted funding reported.

\section{Disclosure}

The authors report no disclosures. Go to Neurology.org/NN for full disclosures.

\section{Publication history}

Received by Neurology: Neuroimmunology \& Neuroinflammation November 5, 2019. Accepted in final form January 23, 2020.

\section{Appendix Authors}

\begin{tabular}{llll}
\hline Name & Location & Role & Contribution \\
\hline Matthew & Neurology & Author & Design and \\
Silsby, MBBS & Department Concord & & conceptualized \\
(Hons), & Repatriation General & study; patient \\
FRACP & Hospital, Sydney, & management; \\
& Australia & drafted manuscript, \\
& & edited and approved \\
& & final draft \\
\hline
\end{tabular}

Appendix (continued)

\begin{tabular}{|c|c|c|c|}
\hline Name & Location & Role & Contribution \\
\hline $\begin{array}{l}\text { Candice J. } \\
\text { Clarke, BSc } \\
\text { (Hons), MSc } \\
\text { (MBT), MBA }\end{array}$ & $\begin{array}{l}\text { Anatomical } \\
\text { Pathology } \\
\text { Department Concord } \\
\text { Repatriation General } \\
\text { Hospital, Sydney, } \\
\text { Australia }\end{array}$ & Author & $\begin{array}{l}\text { Interpreted pathologic } \\
\text { data, revised the } \\
\text { manuscript for } \\
\text { intellectual content, } \\
\text { edited and approved } \\
\text { final draft }\end{array}$ \\
\hline $\begin{array}{l}\text { Kenneth Lee, } \\
\text { MBChB, } \\
\text { FRCPA }\end{array}$ & $\begin{array}{l}\text { Anatomical } \\
\text { Pathology } \\
\text { Department Concord } \\
\text { Repatriation General } \\
\text { Hospital, Sydney, } \\
\text { Australia }\end{array}$ & Author & $\begin{array}{l}\text { Interpreted pathologic } \\
\text { data, revised the } \\
\text { manuscript for } \\
\text { intellectual content, } \\
\text { edited and approved } \\
\text { final draft }\end{array}$ \\
\hline $\begin{array}{l}\text { David } \\
\text { Sharpe, } \\
\text { MRCP(UK), } \\
\text { FRACP }\end{array}$ & $\begin{array}{l}\text { Neurology } \\
\text { Department Concord } \\
\text { Repatriation General } \\
\text { Hospital, Sydney, } \\
\text { Australia }\end{array}$ & Author & $\begin{array}{l}\text { Design and } \\
\text { conceptualized study; } \\
\text { patient management; } \\
\text { drafted manuscript, } \\
\text { edited and approved } \\
\text { final draft }\end{array}$ \\
\hline
\end{tabular}

\section{References}

1. Graus F, Delattre JY, Antoine JC, et al. Recommended diagnostic criteria for paraneoplastic neurological syndromes. J Neurol Neurosurg Psychiatr 2004;75:1135-1140.

2. Gultekin SH, Rosenfeld MR, Voltz R, Eichen J, Posner JB, Dalmau J. Paraneoplastic limbic encephalitis: neurological symptoms, immunological findings and tumour association in 50 patients. Brain 2000;123:1481-1494.

3. Graus F, Titulaer MJ, Balu R, et al. A clinical approach to diagnosis of autoimmune encephalitis. Lancet Neurol 2016;15:391-404.

4. Nanavati A, Zeck J, Philips G, Bade NA. A unique case of pronounced neurologic deficit from paraneoplastic syndrome that precedes appearance of mediastinal germinoma by two years. Case Rep Clin Pathol 2016;3:6-9.

5. Gaillard N, Charif M, Carlander B, Pujol JL, Touchon J. Chemotherapy treatment for anti-Hu paraneoplastic syndrome without active malignancy [in French]. Rev Neurol (Paris) 2006;162:862-865.

6. Harloff A, Hummel S, Kleinschmidt M, Rauer S. Anti-Ri antibodies and limbic encephalitis in a patient with carcinoid tumour of the lung. J Neurol 2005;252:1404-1405.

7. Rojas-Marcos I, Rousseau A, Keime-Guibert F, et al. Spectrum of paraneoplastic neurologic disorders in women with breast and gynecologic cancer. Medicine (Baltimore) $2003 ; 82: 216-223$. 


\section{Neurology \\ Neuroimmunology \& Neuroinflammation}

\section{Anti-Hu limbic encephalitis preceding the appearance of mediastinal germinoma by 9 years \\ Matthew Silsby, Candice J. Clarke, Kenneth Lee, et al. \\ Neurol Neuroimmunol Neuroinflamm 2020;7; \\ DOI 10.1212/NXI.0000000000000685}

This information is current as of February 21, 2020

Updated Information \&

Services

References

Subspecialty Collections

Permissions \& Licensing

Reprints including high resolution figures, can be found at: http://nn.neurology.org/content/7/3/e685.full.html

This article cites 7 articles, 1 of which you can access for free at: http://nn.neurology.org/content/7/3/e685.full.html\#\#ref-list-1

This article, along with others on similar topics, appears in the following collection(s):

Autoimmune diseases

http://nn.neurology.org//cgi/collection/autoimmune_diseases

Paraneoplastic syndrome

http://nn.neurology.org//cgi/collection/paraneoplastic_syndrome

Information about reproducing this article in parts (figures,tables) or in its entirety can be found online at:

http://nn.neurology.org/misc/about.xhtml\#permissions

Information about ordering reprints can be found online: http://nn.neurology.org/misc/addir.xhtml\#reprintsus

Neurol Neuroimmunol Neuroinflamm is an official journal of the American Academy of Neurology.

Published since April 2014, it is an open-access, online-only, continuous publication journal. Copyright

Copyright (C) 2020 The Author(s). Published by Wolters Kluwer Health, Inc. on behalf of the American

Academy of Neurology.. All rights reserved. Online ISSN: 2332-7812.

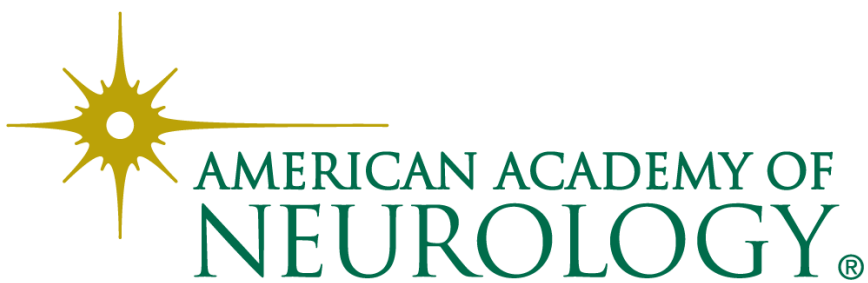

